\title{
Chemical Changes of Shredded Catfish (Clarias gariepinus) Added with Different Concentration of Sucrose During Storage at Room Temperature
}

\author{
Eko Nurcahya Dewi*, Aulleta Affri Nurbaiti, and Lukita Purnamayati \\ Study Program of Fish Product Technology, Faculty of Fisheries and Marine Sciences Diponegoro \\ University, Indonesia
}

\begin{abstract}
Shredded catfish is a processed dried food, usually used as a side dish and stored for a long time. The main criteria of shredded fish selection is its taste, color and appearance. During storage, shredded catfish might be experienced deterioration in quality. Therefore, the purpose of this study was to determine changes in the chemical quality of shredded catfish with different sucrose concentrations during storage. The study was carried out by adding sucrose to the formulation of shredded catfish respectively $27.5 \%$, $32.5 \%$, and $37.5 \%$. For a comparison purposed, commercial shredded catfish with sucrose addition of $35 \%$ was applied. All samples were stored for 60 days and observed every 30 days for the moisture content, $\mathrm{a}_{w}$, color measurement, peroxide value (PV), thiobarbituric acid (TBA), free fatty acid (FFA) and fatty acid profile. The results show that during storage at room temperature shredded catfish with $27.5 \%$ sucrose was the best quality product. During storage there was an increase in moisture content, $\mathrm{a}_{w}, \mathrm{TBA}$ and FFA, while for PV parameters increased in fluctuation at day 30 of storage and decreased at day 60 of storage. Color parameter decreased from dark to slightly bright and unsaturated fatty acids decreased in oleic, linoleic, linolenic and DHA. Based on these results, shredded catfish still safe to be consumed during storage for 60 days or two months.
\end{abstract}

\section{Introduction}

Catfish (Clarias gariepinus) is a potential fish to be cultured since it came with a good meat quality, resistant to disease and has a broad tolerance limits regarding its environtmental condition. Catfish is able to grow in ponds with small flowing water or oxygen [1]. Therefore, catfish production and consumption levels were expected to increase until year of 2028 [2]. Catfish contains high nutrients, as follow $69-74 \%$ of moisture , 18-20\% of protein, $1.1-1.3 \%$ of fat, $2-8 \%$ of carbohydrate, and $1-1.9 \%$ of ash content [3]. Based on the fat content, catfish are included in low-fat fish [4]. The level consumption of processed catfish in the community was not only in the form of fried fish, but also in processed forms such as meatballs, tempura, kaki naga, otak-otak and crackers [5]. However, the most popular catfish as processed products in Indonesia is shredded fish, seasoned fish meat floss or abon ikan lele [6].

\footnotetext{
${ }^{*}$ Corresponding author : nurdewisatsmoko@gmail.com
} 
Shredded meat is a processed product in dry form that made from raw meat, chicken, or fish mixed with spices, fried, reduced the oil content afterwards by pressing or with a tool such as spiner. The main criteria for shredded fish is color, appearance and taste. Huda et al. [7] stated that panelists like meat floss and chicken floss with dark/brown in color and sweet taste. The reaction between sugar and amino acid caused dark browncolor namely Maillard reaction [8]. The brown color intensity was influenced by the type of sugar added. In addition the sugar will also affected the taste of product. Wongwiwat and Wattanachant [9] stated that sucrose and sorbitol in sweet-dried chicken produced the highest sensory score. Therefore, the concentration of sugar added to shredded catfish greatly influenced the color and taste of shredded fish produced.

Shredded fish is a dry product that possibly stored at room temperature in a long time. During storage, the quality of shredded fish would undergo spoilage since the meat was steamed and fried at high temperature of oil during processing . Unsaturated fatty acid of shredded fish is possibly to undergo lipolysis and lipid oxidation during storage at room temperature [10], while the sugar content in the product was able to dehydrate and hydrolyze, influenced by temperature and humidity [11]. The purpose of this study was to determine chemical quality changes of shredded catfish with different sucrose concentrations during storage at room temperature.

\section{Materials and methods}

\subsection{Materials}

Main raw material was a live catfish weighing $\pm 2.3 \mathrm{~kg}$ and $\pm 63 \mathrm{~cm}$ long. Fish obtained from a holding pond at the Marissa Food fish processing unit, Bojongsari, Purbalingga, Central Java, Indonesia. All the spices used such as sucrose, salt, garlic and shallots, coriander, galangal, ginger, lemongrass, orange leaves, bay leaves, tamarind, were approximately $30 \%$ from the total materials. The spices were obtained from traditional market in Semarang, Central Java, Indonesia.

\subsection{Production of shredded catfish}

The production of shredded catfish based on Omojola et al. [12] and applicated in a small scale processor (UKM) at Purbalingga, Central Java with modifications on their sugar addition. Based on the UKM seller information, the best seller of shredded catfish was a product with $35 \%$ sucrose addition on the total fine meat fiber. First, a freshly cleaned wholes catfish were steamed for 45 minutes with the addition of bay leaves, orange leaves and lemongrass to remove fishy odor. Then, the meat was separated from the bone and skin and shredded to form fine meat fibers. The mashed spices were added include coriander, ginger, garlic, shallots sauteed together with salt, and sucrose respectively. The mixture was stir-fried until the seasonings and sucrose melted, followed by mixing shredded catfish and fried for \pm 15 minutes using the pan frying method, which is a method of frying using a small amount of oil. The frying was continued with deep frying method using large amounts of oil until the entire surface of the materials were submerged at a temperature of $180^{\circ} \mathrm{C}$ for 50 minutes. The cooked shredded catfish then drained to remove the oil content using a spinner with a speed of $1000 \mathrm{rpm}$ for 30 seconds. Shredded fish were packed afterwards using polypropylene plastic and sealed. The treatments in this experiment were the addition of different sucrose concentration of $27.5 \%$ (A), 32.5\% (B), and $37.5 \%$ (C). The percentage of sucrose added was based on the weight of the total fine shredded catfish meat fiber. As a comparison, different treatment of shredded catfish control were applied, namely sucrose 
(white sugar) addition of 35\% (KS), 35\% sucrose and brown sugar (KSR), and 35\%brown sugar (KR). Shredded catfish stored at room temperature for 60 days and tested every 30 days.

\subsection{Analysis}

\subsubsection{Moisture content, $\mathrm{a}_{w}$ and color measurement}

Shredded catfish moisture content analysis was carried out based on AOAC [13]. Water activity analysis was carried out using $\mathrm{a}_{w}$ meter (Hygropalm HP23 $\mathrm{a}_{w}$ A Set of Rotronic 40). The color measurement was tested using Chromameter (Konica Minolta CR-410). The working principle of a color reader is a color exposure system using the $\mathrm{L}^{*} \mathrm{a} * \mathrm{~b} *$ Hunter. $\mathrm{L}^{*}$ scale shows the lightness/darkness of the sample, where a low number (0-50) indicates darkness and a high number (51-100) indicates lightness. The value of $+\mathrm{a}^{*}$ scale indicates redness, meanwhile $+b^{*}$ scale indicates yellowish.

\subsubsection{Peroxide value}

Peroxide value (PV) was measured by weighing a sample of 5 gram then added with acetatechloroform acid (3: 2) as much as $30 \mathrm{ml}$ then homogenized [14]. The solution was added to $0.5 \mathrm{ml}$ saturated $\mathrm{KI}$ and stored in a dark place for 2 minutes added with $30 \mathrm{ml}$ of distilled water and $1 \%$ starch solution in 4 drops and titrated withNa $\mathrm{S}_{3} \mathrm{O}_{3} 0.05 \mathrm{~N}$ until becomes clear. $\mathrm{PV}$ is expressed in meq $\mathrm{O}_{2} / \mathrm{kg}$ and calculated by the following formula:

$\mathrm{PV}=\left(\left(\mathrm{V} \mathrm{Na} \mathrm{S}_{2} \mathrm{O}_{3}\right.\right.$ samples $-\mathrm{V} \mathrm{Na}_{2} \mathrm{~S}_{2} \mathrm{O}_{3}$ blanko $\left.) \times \mathrm{N} \mathrm{Na}_{2} \mathrm{~S}_{2} \mathrm{O}_{3} \times 1000\right) /$ sample weight

\subsubsection{Thiobarbituric acid}

Thiobarbituric acid (TBA) was analyzed according to Tokur and Korkmaz [15] by weighing a sample of 0.5 gram, adding $50 \mathrm{ml}$ of distilled water and $2.5 \mathrm{ml} \mathrm{HCl}$ to distillation process. The distillation result of $5 \mathrm{ml}$ added with $5 \mathrm{ml}$ of TBA reagent then heated for 30 minutes and cooled. The solution was monitored for its absorbance at a wavelength of $528 \mathrm{~nm}$. The value expressed in $\mathrm{mg}$ of malonaldehyde / $\mathrm{kg}$ of oil.

\subsubsection{Free fatty acid}

Free fatty acids (FFA) analysis was based on Farvin et al. [16] by weighing a sample of 10 gram, adding $15 \mathrm{ml}$ of ethanol, and then homogenized. The phenolphthalein indicator was added to 5 drops and titrated with $0.1 \mathrm{M} \mathrm{NaOH}$. FFA was calculated in $\%$ oleic acid $(\mathrm{BM}=$ 256). \% FFA $=(\mathrm{BM}$ oleic acid $\times \mathrm{V} \mathrm{NaOH} \times 100 \%) /$ sample weight

\subsubsection{Fatty acid composition}

The sample of $0.5 \mathrm{ml}$ was added with 1.5 sodium metanolic solution and heated at $70{ }^{\circ} \mathrm{C}$ for 10 minutes. The mixture was cooled and $2 \mathrm{ml}$ of Boron trifluoride metanoate was added and reheated at $70^{\circ} \mathrm{C}$ for 10 minutes, then added with $1 \mathrm{ml}$ saturated $\mathrm{NaCl}$ afterwards [17]. Sample was inserted into the Eppendorf tube, $1 \mu \mathrm{L}$ of extract was injected into gas chromatography (Shimadzu, Japan) equipped with a FID detector (Shimadzu, Japan) with a $30 \mathrm{~cm}$ Sil 8CB CP column. 


\subsubsection{Statistical Analysis}

This study was carried out with three replications of treatments. The collected data were analyzed using ANOVA and Tukey's test in order to determine the differences between the treatments.

\section{Results and discussion}

\subsection{Moisture content}

Moisture content on shredded catfish increased in line with the sucrose concentration, characterized by more watery shredded catfish. Sugar would keep the food stiff indicated by the highest moisture content found in shredded catfish with high concentration of sugar, such as treatment $\mathrm{C}$ and control, which were $7.71 \%$ to $8.59 \%$. The lowest moisture content was found in shredded catfish A with the value of $6.51 \%$ (Fig. 1). During room temperature storage, shredded catfish experienced an increase in moisture content both on shredded catfish sample treatments and controls. Sucrose has a hydrophilic group that affects the plasticity and moisture of the product. The rate of absorption of moisture was affected by purity and crystal structure [18]. This attributes caused an increase in moisture content during storage. In addition, it was also influenced by air humidity and storage temperature [11].

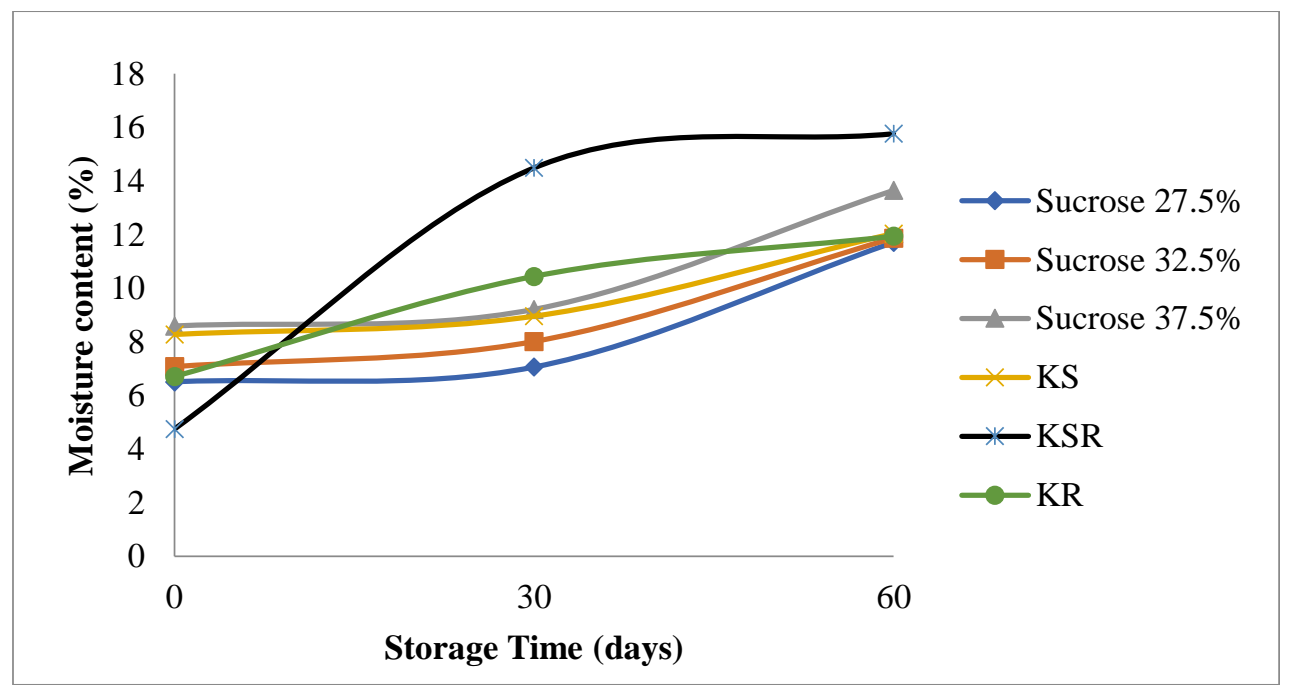

Fig 1. Moisture content of shredded catfish added with different concentration of sugar during storage

The moisture content of each shredded catfish produced with different sucrose concentrations relatively have met the moisture content requirement according to the Indonesian National Standard (SNI 7690.3:2013) [19] regarding shredded catfish quality which are a maximum of $15 \%$, except for KSR, at 60th day storage, the moisture content reached $15.78 \%$ (Fig.1). This was because of sucrose and brown sugar combination produced a more hygroscopic nature than adding sucrose or brown sugar alone. Based on the hygroscopic nature, brown sugar would be damaged then turned into runny consistency for one or two weeks [20]. This result was in accordance with Frans et al. [21], which stated that 
production of sardine jerky with the addition of sugar would increase the moisture content during storage.

\section{$3.2 A_{w}$}

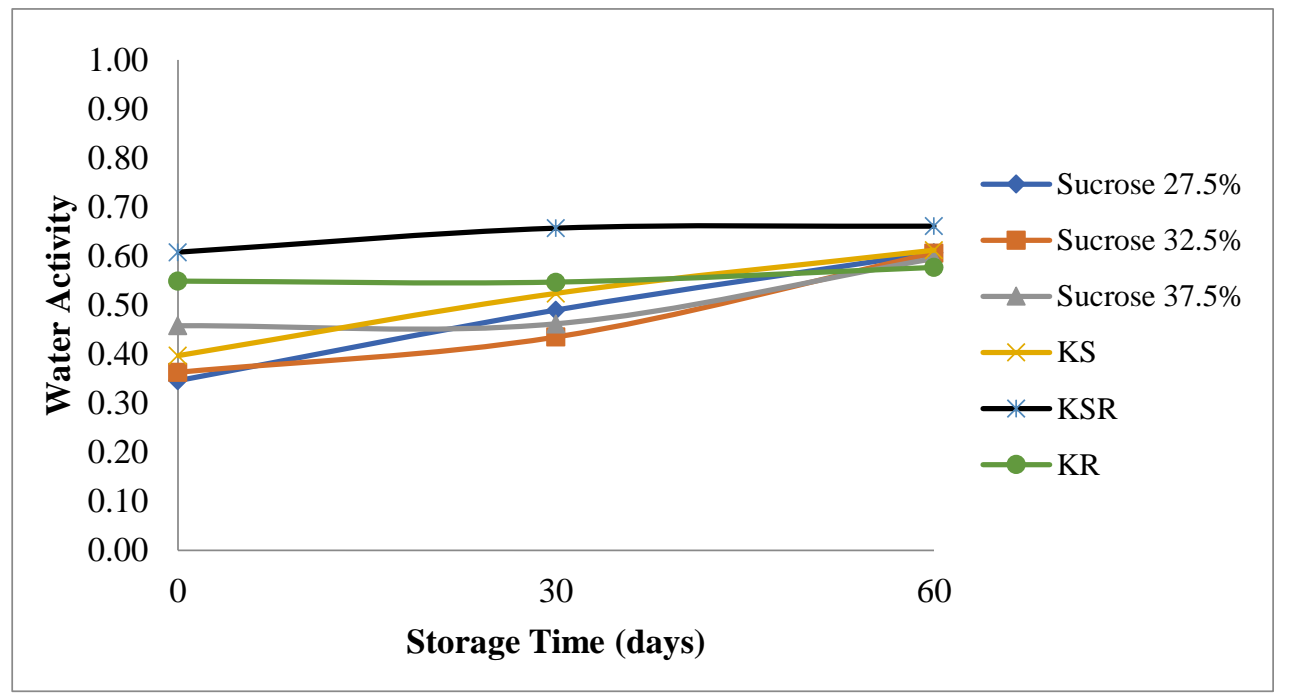

Fig 2. Water activity of shredded catfish added with different concentration of sugar during storage

Shredded catfish A, B, and C experienced an increase in water activity during storage. This also occured in KS and KSR. The enhancement in moisture content was possible due to the amount of sucrosa added, along with water activity. The shredded catfish with sucrose addition has a lower $\mathrm{a}_{w}$ would more likely to bind the water around, due to osmosis balance between shredded catfish and the surrounding environment during storage. Pursudarsono et al. [22] stated that the treatment of sugar concentration had a significant effect on beef jerky $\mathrm{a}_{w}$ value, and it was concluded that in those treatment the $\mathrm{a}_{w}$ value tended to increase, namely $0.61-0.64$ (Fig. 2). These value were higher than the results of this study which were 0.34 - 0.40 due to the use of sugar concentrations in beef jerky were lower than in shredded catfish. Furthermore, the product was only packed on the plastic sealed not in a vacuum pack sealer so the air outside packaging easier to get inside.

The relationship between water content and water activity $\left(\mathrm{a}_{w}\right)$ in this study was positive correlation, as evidenced by the increasing of moisture content during storage. There was a correlation between water activity and moisture content. The higher the moisture content, the higher the water activity [23].

\subsection{Color measurement}

Based on the evaluation of the shredded catfish color, the brightest color was found in shredded catfish A and the darkest color was seen in shredded catfish C, which even darker than commercial shredded catfish with brown sugar addition (Table 1). This color difference has a close relationship with the amount of sucrose added to shredded catfish. The more sucrose was added, the caramelization process would be greater as a result darker/brown color. In addition to the caramelization, browning occured due to the Maillard reaction during high-temperature frying process. Sucrose acts to make foods look appealing with brown 
color, through caramelization from heated sugar or from Maillard result compounds between sugar and amino acids contained in food proteins [24]. The addition of sugar aimed to give desired sweetness and brown color. The addition of sugar to the mushroom shredded was about $10 \%$ produces a brown color to the shredded. The use of sugar must be controlled and limited because it could cause the color would be too dark [25].

Tabel 1. Color measurement of shredded catfish added with different concentration of sugar

\begin{tabular}{ccccc}
\hline Sample & $\begin{array}{c}\text { Storage Time } \\
\text { (days) }\end{array}$ & $\mathrm{L}^{*}$ & $+\mathrm{a}^{*}$ & $+\mathrm{b}^{*}$ \\
\hline Sucrose27.5\% & 0 & $44.18^{\mathrm{a}}$ & $10.67^{\mathrm{c}}$ & $17.18^{\mathrm{c}}$ \\
& 30 & $51.05^{\mathrm{c}}$ & $10.04^{\mathrm{c}}$ & $13.06^{\mathrm{ab}}$ \\
Sucrose 32.5\% & 60 & $52.62^{\mathrm{c}}$ & $9.42^{\mathrm{bc}}$ & $14.71^{\mathrm{bc}}$ \\
& 0 & $42.43^{\mathrm{a}}$ & $8.38^{\mathrm{a}}$ & $13.74^{\mathrm{ab}}$ \\
Sucrose 37.5\% & 30 & $49.00^{\mathrm{bc}}$ & $9.20^{\mathrm{abc}}$ & $11.82^{\mathrm{ab}}$ \\
& 60 & $48.92^{\mathrm{bc}}$ & $10.65^{\mathrm{c}}$ & $17.63^{\mathrm{c}}$ \\
KS & 0 & $41.59^{\mathrm{a}}$ & $8.04^{\mathrm{a}}$ & $10.38^{\mathrm{a}}$ \\
& 30 & $47.36^{\mathrm{bc}}$ & $8.29^{\mathrm{a}}$ & $11.28^{\mathrm{a}}$ \\
& 60 & $46.96^{\mathrm{bc}}$ & $8.94^{\mathrm{ab}}$ & $12.04^{\mathrm{ab}}$ \\
KSR & 0 & $42.13^{\mathrm{a}}$ & $8.28^{\mathrm{a}}$ & $11.92^{\mathrm{ab}}$ \\
& 30 & $49.74^{\mathrm{c}}$ & $9.31^{\mathrm{abc}}$ & $10.78^{\mathrm{a}}$ \\
KR & 60 & $48.51^{\mathrm{bc}}$ & $9.35^{\mathrm{abc}}$ & $12.24^{\mathrm{ab}}$ \\
& 0 & $54.91^{\mathrm{c}}$ & $7.09^{\mathrm{a}}$ & $21.92^{\mathrm{d}}$ \\
& 30 & $54.12^{\mathrm{c}}$ & $9.35^{\mathrm{abc}}$ & $21.51^{\mathrm{d}}$ \\
& 60 & $54.95^{\mathrm{c}}$ & $9.31^{\mathrm{abc}}$ & $17.23^{\mathrm{c}}$ \\
& 0 & $42.82^{\mathrm{a}}$ & $7.20^{\mathrm{a}}$ & $10.37^{\mathrm{a}}$ \\
& 30 & $41.91^{\mathrm{a}}$ & $8.54^{\mathrm{ab}}$ & $9.92^{\mathrm{a}}$ \\
& 60 & $40.80^{\mathrm{a}}$ & $7.93^{\mathrm{a}}$ & $7.62^{\mathrm{a}}$ \\
\hline
\end{tabular}

Note : The different superscript in the same column indicate significant differences $(\alpha=0.05)$

Note $*=L^{*}$ shows light $/$ dark, $+a^{*}=$ shows redness $+b^{*}$ show yellowish color

The lowest sucrose concentration had a higher brightness than the highest sucrose concentration. This was caused by caramelization reaction with sugar cooked at high temperature and result in browning. If the amount of sugar continued to be added, the darker color would be produced. Pursudarsono et al. [22], stated that at the end of the Maillard reaction, a brown pigment was formed in the beef jerky with sugar and salt. Factors that influenced the Maillard reaction are temperature, concentration and type of sugar. Aside from that, browning is caused by caramelization due to the degradation of sugar at high temperatures.

The lowest $\mathrm{a}^{*}+$ value were shredded catfish B, C, and control namely 8.04-9.37 (red color) and the value increased with decreasing concentration of cane sugar given to shredded catfish (Table 1). Shredded catfish A had the highest $a^{*}+$ value compared with other samples which was 10.67 . The value of $\mathrm{a}^{*}+$ decreased for all shredded samples during storage that indicated the redness. The higher $\mathrm{a}^{*}+$ value indicated that the product was a brighter red, while the lower the value of $a^{*}+$ indicated the product was a darker red. The color change happened due to cooking with high temperature, resulting in a Maillard reaction between reducing sugars and amino acids contained in catfish meat protein, in which the value of $\mathrm{a}^{*+}$ or red color would get darker. The redness color measurement of pumpkin lempok product with heat caused a browning due to sugar, so the caramelization process occured and sharpen the color to produce a brownish color. Maillard reaction also occured between reducing sugars and amino acids which produced brown pigment called melanoidin [26].

The highest value of $b^{*}+$ was shredded catfish A namely 17.18 . The lowest $b^{*}+$ value was shredded catfish $C$ namely 10.38. The value of $b^{*}+$ decreased for all samples during 
storage. The low value of $b^{*}+$ indicated a darker yellow color and vice versa. Based on the values of $\mathrm{L}^{*}, \mathrm{a}^{*}$, and $\mathrm{b}^{*}$ (Table 1) shredded catfish samples during storage decreased so the color became bright. This is in accordance with Baraiya et al. [27] which stated that the color of shrimp snacks has decreased during storage due to interaction between maillard reaction products and components in the product.

\subsection{PV and TBA}

Peroxide value (PV) and TBA value are used to measure the oxidation level of oils. Peroxide is an intermediate reaction by-product which in the next stage would form aldehydes and ketones that caused rancid odors. The formation of peroxide is slow at the initial storage, it would increase rapidly later depend on fat content and the presence of antioxidants. TBA is used to measure the amount of unsaturated fatty acid in a product. The higher the TBA value, the more rancid the product will be [28].

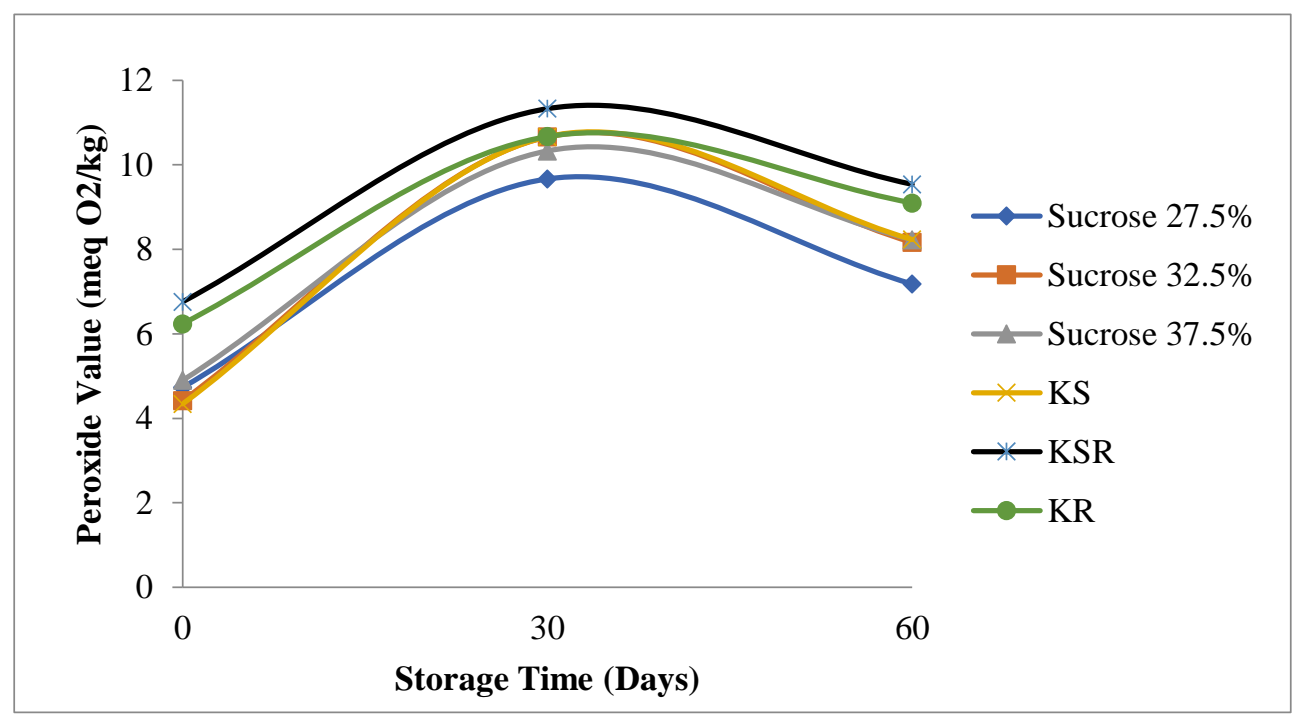

Fig 3. Peroxide value of shredded catfish added with different concentration of sugar during storage

$\mathrm{PV}$ is an indicator of the extent of fat or oil damage in food, characterized by change in flavor. Cooking in general could accelerate rancidity by releasing Fe from protein and damaging the tissue. PV measured on shredded catfish were 4.34 meq $\mathrm{O}_{2} / \mathrm{kg}$ up to 4.89 meq $\mathrm{O}_{2} / \mathrm{kg}$ (Fig. 3). These results were below the value of PV from commercial shredded catfish. During storage, all samples increased in PV at the first 30 days of storage, while at the last 60 days storage there has been decreased. The decreased of PV indicated that hydroperoxide compound were degraded into further compound of lipid oxidation namely malonaldehyde.

The maximum peroxide value for shredded catfish products had not been determined by certain standards, however the extent of acceptance of PV as measured by the iodometric titration method should not be more than 15 meq $\mathrm{O}_{2} / \mathrm{kg}$ [29]. The PV in cooking oil should not be more than 10 meq $\mathrm{O}_{2} / \mathrm{kg}$. The increase in PV likely occured during cooking process with the deep fat frying method and stirring, allowing aeration to occur as result in higher oxidation [30]. PV is the most important to determine the level of oxidation caused by air [31]. The heating of cooking oil for a long time and high temperatures, especially at atmospheric pressure allowed contact between cooking oil and oxygen in the air. This 
indicated that free air containing oxygen could have contact with cooking oil at high temperature conditions, and cause oil and fat to oxidized [32].

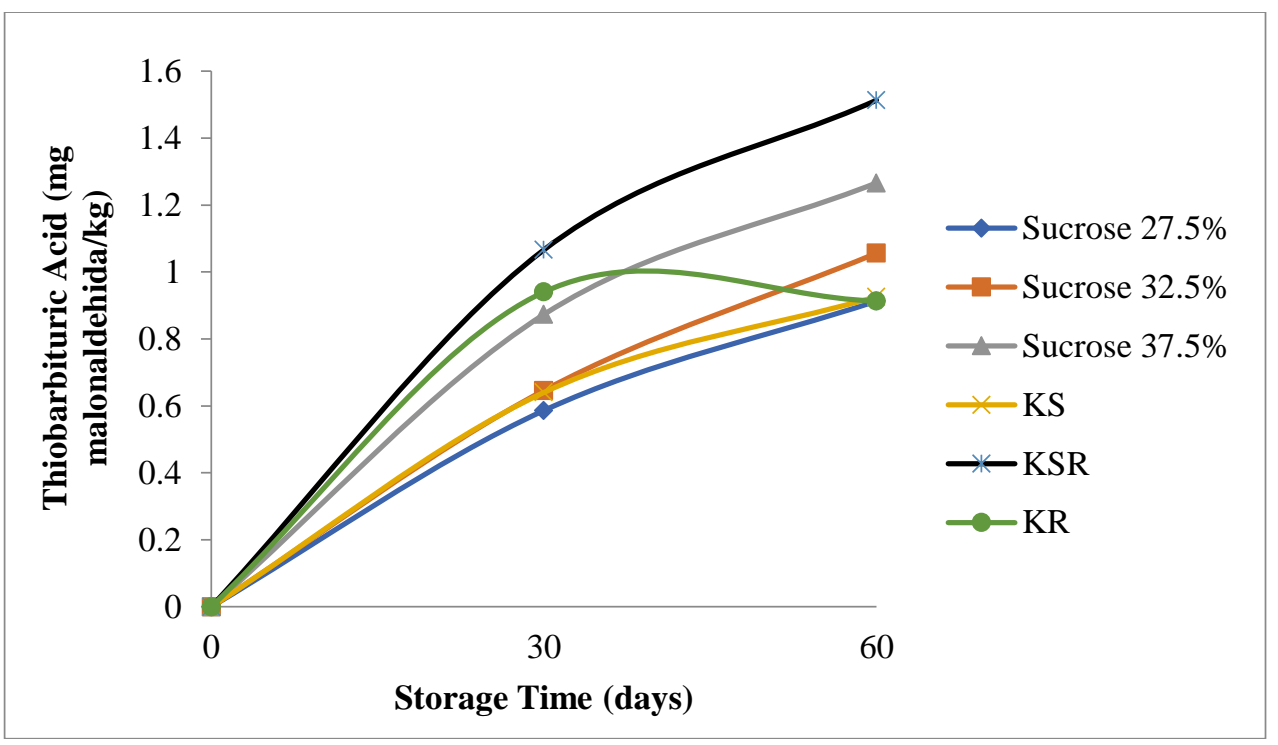

Fig 4. TBA value of shredded catfish added with different concentration of sugar during storage

Secci and Parisi [33] explained that oxidation is a reaction that mainly impact food quality, especially for products with high unsaturated fat content. Declained in product quality, unpleasant odors and flavors, shortened shelf life, decreased nutritional value, and formation of harmful compounds are some of the results of fat oxidation in food. The use of high temperatures during cooking has a great impact on the characteristics and composition of food along with increasing in fat oxidation. Ucak et al. [34] stated that the PV for all products would continue to increase until the seventh day of storage and then would decline afterwards as long as the storage was done. PV were closely related to TBA.

The value of TBA in shredded catfish at the beginning of storage had not been formed yet, whereas in the 30 days storage began to form malonaldehyde and continued to increase until the 60 days storage (Fig. 4). The maximum limit for TBA value in food is $5 \mathrm{mg}$ malonaldehyde $/ \mathrm{kg}$ [35], there for the storage for 60 days, TBA value is still below the maximum limit.

\subsection{FFA}

Free fatty acid (FFA) is an indicator to measure the extent of hydrolysis in fat based on variance analysis result, the difference in sucrose concentration did not show any significant effect to FFA value on shredded catfish. The range of FFA measured on shredded catfish was $0.62 \%$ to $0.76 \%$ and continued to increase during storage time. The formation of FFA in shredded catfish due to the presence of water in catfish fried in oil as a medium. This was proven by Nayak et al. [36], if the frying process occurred under considerable amount of water, the oil would undergo hydrolysis and produced free fatty acids, fatty acid triglycerides, and glycerol. Free fatty acids and fat oxidation or their products would react with proteins, in some cases it might result in deterioration in product quality. The accumulation of FFA values not only has an impact on the quality of the product's properties, but also shown to be 
related to fat oxidation. The oxidation of unsaturated fatty acids or triglycerides in fish produced free radical formation through hydroperoxide fat decomposition [37].

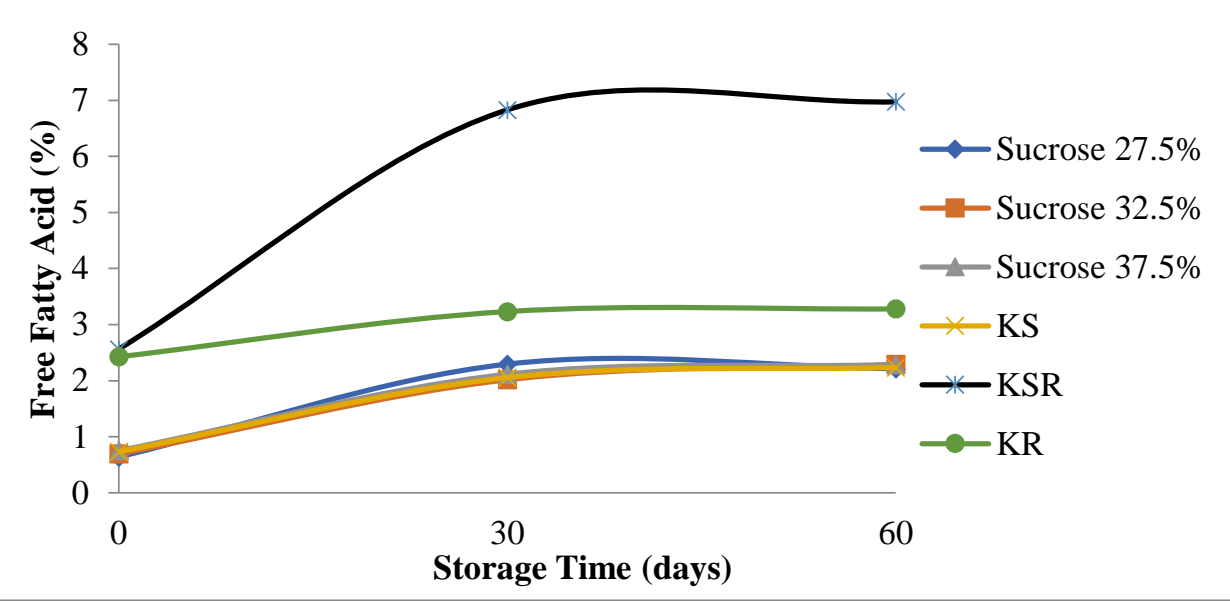

Fig 5. FFA value of shredded catfish during storage

According to SNI 3741:2013 for cooking oil [38], the maximum cooking oil of acid value was not more than $0.60 \%$, whereas in the study of shredded catfish, the measurement of free fatty acid numbers was $0.62 \%$ to $0.76 \%$. This value was greater than the SNI because samples were made from raw catfish containing high fat content, fried with excess oil at high temperatures, thereby allowing an increase in free fatty acids. KR and KSR have a significant increase in free fatty acid levels during storage period since breakdown of lipid already taking place.

There was in accordance to shredded catfish moisture content result according to Indonesian National Standards regarding to shredded catfish quality requirements [19] was below $10 \%$, with the result free fatty acid formed was also less than $0.6 \%$. The hydrolysis reaction in oil occured because there was a certain amount of lipid that convert it to free fatty acids and glycerol [39]. The reaction of free fatty acid formation in oil involved water as its reactant, it concluded that the lower the water content, the lower the level of free fatty acids due to the presence of water in oil and easier to experienced hydrolysis [40].

\subsection{Fatty acid composition}

Fatty acid profile of various shredded catfish was presented on Table 2. Fatty Acid samples is represented by shredded $\mathrm{B}$ is the best quality The result of fatty acid composition compared to KS at both day 0 and day 30 of storage. The result showed that the unsaturated fatty acid composition of shredded catfish were dominanted by Saturated Fatty Acid that is palmitic acid, oleic acid and, linoleic acid, and the poly anusaturated fatty acid DHA (Omega-6) and mono unsaturated fatty acid Arachidonic acid. During storage of day 0 to day 30 tends to decrease slightly. Tenyang et al. [41] stated that the content of unsaturated fatty acids in fried catfish were palmitoleic acid, oleic acid, linoleic acid, linolenic acid, and DHA. The declined in unsaturated fatty acids in shredded catfish during storage due to the process of lipid hydrolysis and oxidation on the product. 
Table 2. Fatty acid profile of shredded catfish

\begin{tabular}{clcccc}
\hline & & \multicolumn{4}{c}{ Percentage (\%) } \\
\cline { 3 - 6 } No & \multicolumn{1}{c}{ Fatty Acid } & $\begin{array}{c}\text { B } \\
\text { (day }\end{array}$ & $\begin{array}{c}\text { B } \\
\text { (day }\end{array}$ & $\begin{array}{c}\text { KS } \\
(\text { day }\end{array}$ & $\begin{array}{c}\text { KS } \\
\text { (Day }\end{array}$ \\
& & nd & 30) & $0)$ & $30)$ \\
\hline 1. & Capacolic Acid (C8: 0) & nd & 2.54 & nd \\
2. & Capric Acid (C10: 0) & 0.02 & 0.06 & 2.17 & nd \\
3. & Lauric Acid (C12: 0) & 0.24 & 0.21 & 17.79 & 0.16 \\
4. & Myristic Acid (C14: 0) & 0.96 & 0.94 & 6.45 & 0.70 \\
5. & Palmitic Acid (C16: 0) & 33.20 & 35.00 & 7.01 & 28.78 \\
6. & Palmitoleic Acid ( C16: 1) & 005 & 0.31 & 0.10 & 0.39 \\
7. & Stearic Acid (C18: 0) & 2.98 & 3.41 & 1.25 & 2.82 \\
8. & Oleic Acid (C 18: 1n9C & 42.74 & 40.79 & 36.78 & 33.53 \\
9. & Linoleic Acid ( (C:18:2n6) & 11.34 & 10.90 & 8.61 & 1.83 \\
10. & Linolenic Acid C 18: 3 n3 & 0.23 & 0.19 & 0.20 & 0.18 \\
11. & Erukic Acid (22: 1) & nd & Nd & nd & nd \\
12. & Lignoseric Acid (24: 0) & nd & 0.05 & nd & 0.18 \\
13. & EPA (C20: 5n3) & nd & Nd & nd & nd \\
14. & DHA (C22: 6n3) & 0.26 & 0.06 & 0.18 & 0.08 \\
15. & Arachidonic Acid (C & 0.24 & 0.23 & 0.05 & 0.11 \\
& 20:4n6) & & & & \\
\hline
\end{tabular}

Note : nd : non detected

\section{Conclusion}

Based on the chemical properties during storage at room temperature shredded A using $27.5 \%$ sucrose addition is the best quality shredded catfish from the parameter of water content, $\mathrm{a}_{w}, \mathrm{PV}, \mathrm{TBA}, \mathrm{FFA}$ and color. During storage 60 days, peroxide value was unstable and TBA value slight increased. The color parameter changed from dark to slightly bright and unsaturated fatty acids compounds decreased in oleic, linoleic, linolenic and DHA. Based on the chemical analysis indicated that shredded catfish sample were still suitable for consumption during 60 days storage for at the room temperature.

\section{Acknowledgment}

The authors would like to thank to Faculty Fisheries and Marine Sciences, Diponegoro University for funding this research with fiscal year of 2018.

\section{References}

1. S. Hastuti, Subandiyono, J Saintek Pi, 10, 1, 37-42 (2014)

2. N. Tran, U. Rodriguez, C. Yee, M. John, V. Mohan, P. John, S. Hall, Marine Policy, 79, 25-32 (2017)

3. R. J. Solomon, A. R. Oluchi, J of Fisheries \& Livestock Production, 6, 2 (2018)

4. B. P. Mohanty, S. Ganguly, A. Mahanty, T. V. Sankar, R. Anandan, K. Chakraborty, N. Sridhar, Biomed Research International, 1-14 (2016)

5. Rario. IOSR Journal of Environmental Science, Toxicology, and Food Technology, 9, $15,18-25(2015)$ 
6. Supriatna, M. Mahmudi, P. Winajarko, J of Innovation and Applied Technology, 4, 1, 544-551 (2018)

7. N. Huda, Y. Fatma, A. Fazillah, F. Adzitey, Pakistan Journal of Nutrition, 11, 1, 1-4 (2012)

8. Karseno, Erminawati, T. Yanto, R. Setyowati, P. Haryanti, Food Research, 1-7 (2018)

9. P. Wongwiwat, S. Wattanachant, IFRJ, 21(6), 2285-2291 (2014)

10. F. J. Méndez-cid, J. A. Centeno, S. Martínez, J. Carballo, J of Food Composition and Analysis, 63, 121-132 (2017)

11. C. L. Aguiar, A. L. B. Rocha, J. R. Jambassi, A. S. Baptista, R. B. Lima, Focusing on Modern Food Industry, 4, 1-10 (2015)

12. A. B. Omojola, O. R. Kassim, O. O. Olusola, P. O. Adeniji, J. O. Aremo, British Journal of Applied Science \& Technology, 4, 26, 3862-3873 (2014)

13. AOAC, Washington DC (2005)

14. AOCS, Illinois: Am Oil Chem Soc Press, Champaign (2012)

15. B. Tokur, K. Korkmaz, Food Chemistry, 104, 754-760 (2007)

16. S. Farvin, H. D. Grejsen, C. Jacobsen, Food Chemistry, 131, 843-851 (2012)

17. R. Husain, Suparmo, E. Harmayani, C. Hidayat, Agritech, 37, 3, 319-326 (2017)

18. R. Moreira, F. Chenlo, M. D. Torres, D. M. Prieto, Advances in Food Science and Engineering, 1, 1, 18-27 (2017)

19. Badan Standardisasi Nasional, SNI 7690.1:2013 (2013)

20. M. Meenune, P. Naknean, IPCBEE, 53, 66-70 (2013)

21. S. K. Frans, A. I. R. Detha, E. Tangkonda, J Kajian Veteriner, 4, 2, 28-39 (2016)

22. F. Pursudarsono, D. Rosyidi, A. S. Widati, J Ilmu dan Teknologi Hasil Ternak, 10, 1, 35-45 (2015)

23. C. Chen, Foods, 8, 30, 1-18 (2019)

24. A. Golon, C. Kropf, I. Vockenroth, N. Kuhnert, Foods, 3, 461-475 (2014)

25. W. Widyastuti, T. Karo-karo, L. M. Lubis, J. Rekayasa Pangan dan Pertanian, 5, 3, 534 540 (2017)

26. O. W. Nilasari, W. H. Susanto, J. M. Maligan, J Pangan dan Agroindustri, 5, 3, 15-26 (2017)

27. K. G. Baraiya, S. M. Zofair, V. B. Mulye, S. R. Lende, R. A. Khileri, R. M. Kadri, M. R. Patel, J of Applied and Natural Science, 8, 3, 1366-1374 (2016)

28. H. R. Gheisari, Veterinary World, 4, 4, 153-157 (2011)

29. C. Alimentarius, Codex Stan, 210, 1-16 (2013)

30. S. Naseri, M. Hassan, A. Rreza, S. Molaghen, Arch Hyg Sci, 7, 2, 91-97 (2018)

31. R. L. R. Silalahi, D. P. Sari, I. A. Dewi, Industria: J Teknologi dan Manajemen Agroindustri, 6, 1, 41-50 (2017)

32. F. De Alzaa, C. Guillaume, L. Ravetti, Acta Scientific Nutritional Health, 2, 6, 2-11 (2018)

33. G. Secci, G. Parisi, Italian Journal of Animal Science, 15, 1, 124-136 (2016)

34. I. Ucak, Y. Ozogul, M. Durmus, Int J of Food Science \& Technology, 46, 1157-1163 (2011)

35. U. A. Gunsen, Ozcan, A. Aydin, Turkish Journal of Fisheries and Aquatic Sciences (2011)

36. P. K. Nayak, U. Dash, K. Rayaguru, K. R. Krishnan, J of Food Biochemistry (2015)

37. A. B. Amaral, M. V. Da Silva, S. C. Lannes, Food Science and Technology, 38, 1, 1-15 (2018)

38. Badan Standarisasi Nasional, SNI 3741:2013 (2013)

39. A. B. Rantawi, A. Mahfud, E. R. Situmorang, Industrial Engineering Journal, 6, 1, 3642 (2017)

40. I. F. Ulfindrayani, Q. A'yuni, Journal of Pharmacy and Science, 3, 2, 17-22 (2018) 
41. N. Tenyang, H. M. Womeni, B. Tiencheu, N. Hrodrik, T. Foka, F. Mbiapo, M. Linder, Food and Nutrition Sciences, 4, 176-187 (2013) 